\title{
Research on the Training Mode of Graduate Students of Master Degree in Journalism and Communication
}

\author{
Wanhong Pang \\ Xi'an International University, Xi'an, Shaanxi, 710077, China \\ 444869186@qq.com
}

\begin{abstract}
Keywords: Master of journalism and communication; Professional degree; Graduate student; Training mode
\end{abstract}

\begin{abstract}
In order to improve the training mode of the Master of Journalism and Communication, the investigation and research method is adopted to analyze the problems in MJC training. In the training of MJC, there are some problems such as the lack of professional degree features, the structural defects of teachers and the difficulty in implementing double tutors system. In order to improve the MJC training mode, we should start with defining the professional orientation, adjusting the curriculum system, optimizing the selection of tutors, and improving the tutor management mechanism.
\end{abstract}

\section{Introduction}

The establishment of MJC(Master of Journalism and Communication), a master's degree in journalism and communication, is designed to meet the urgent needs of relevant talents in the development of our country's news and communications. Its purpose is to improve the talent training system of journalism and communication, to innovate talent training mode of journalism and communication, and to improve the quality of news and communication talents[1]. It was approved by the degree committee of the State Council in 2010 and began to recruit students in 2011. After the rapid development in recent years, the enrollment scale of MJC and the number of students have exceeded the academic master of journalism and communication. This article participates in the research project of the teaching and guidance committee of the journalism and communication of the Ministry of Education: "the status quo of journalism and communication specialty and the national standard research and analysis report of teaching quality". In this process, through the analysis of MJC talent training in colleges and universities in Shanxi Province, this paper puts forward the countermeasures of improving MJC talent training mode.

\section{Problems in the Training of Graduate Students of Journalism and Communication}

Professional Degree Features Are Not Distinct. At the beginning of establishment of MJC professional degree, the MJC Teaching Steering Committee issued a guidance training program. Based on this, colleges and universities have formed their own training programs. However, as far as the research institutes are concerned, the characteristics of the professional degree are not clear and the distinction with the academic degree is not high. The academic degree is oriented toward academic research, with emphasis on theory and research. However, professional degree-oriented professional practice places emphasis on practice and application and fosters high-level professionals who are professionally and technically formalized to a high level of training[2]. The actual situation is not satisfactory. From the investigation of a number of colleges and universities in Shanxi MJC training programs, the academic goal of training master's degree is to "cultivate independently high-level talents engaged in journalism research and news editing practice". The training goal of the master of journalism and communication is to "cultivate high-level applied talents of journalism and communication". The training goal of professional degree has removed the words "engaged in journalism research" in the goal of academic degree training. 
Table 1 Comparison of MJC and Academic Master Training Objectives between the Two Universities

\begin{tabular}{|c|l|l|}
\hline \multicolumn{1}{|c|}{ Degree } & \multicolumn{1}{|c|}{ Academic degree } & \multicolumn{1}{c|}{ Professional degree } \\
\hline Aniversity & $\begin{array}{l}\text { Cultivate high-level talents } \\
\text { engaged in journalism } \\
\text { research and news gathering } \\
\text { and editing practices. }\end{array}$ & $\begin{array}{l}\text { Cultivate high-level applied talents } \\
\text { in journalism and communication. }\end{array}$ \\
\hline B & $\begin{array}{l}\text { Cultivate the compound } \\
\text { talents who have mastered } \\
\text { the theory of journalism and } \\
\text { communication and business } \\
\text { skills and attach equal } \\
\text { importance to both } \\
\text { application and research. }\end{array}$ & $\begin{array}{l}\text { Cultivate high-level and applied } \\
\text { talents who are skilled in journalism } \\
\text { and communication skills and } \\
\text { methods and adapt to the } \\
\text { development of journalism and } \\
\text { communication. }\end{array}$ \\
\hline
\end{tabular}

In terms of training links, the differences between the two degree types have not been widened, and the distinction between academic degrees and professional degrees has become more and more vague. Journalism and Communication Studies is a highly practical discipline[3]. Most academic masters also practice in relevant fields after graduation, and only a few of them continue to engage in journalism and communication studies. Various training units in the academic training of graduate students attach great importance to the application and practice. However, the training of professional degree graduates, from daily teaching, tutor guidance to the writing and evaluation of dissertations, is not much different from that of academic masters, which leads to two kinds of degree types in training links. Except for different educational systems, other links are basically the same. What is the significance of establishing a new type of professional degree in the long run?

Curriculum System Is Not Reasonable Enough. The construction of the curriculum system is the key link of the training of talents. After the training of master's degree in journalism and communication, after five or six years of practice, we should conscientiously summarize and reflect on the problems and improve the curriculum system as soon as possible.

According to the opening of graduates programs in some news and information departments of colleges and universities, there is a similar or even identical curriculum for graduates of professional degrees and academic degrees. [4] The word "research" is generally added after the academic master's course, while professional degrees are not added. For example, the professional courses of master of journalism (academic degree) include: news interview writing research, news editing research, news commentary research, and etc., and the professional courses of master of journalism and communication include: news interview and writing, news editor and comment, news practice research. This kind of course setting is obviously difficult to adapt to the training requirements of graduates of professional degrees.

In addition, the main courses of graduate students with professional degrees are consistent with the contents of undergraduate courses, and there is no difference in teaching methods, which makes the advantages of graduates with professional degrees less obvious than that of undergraduates. Professional basic courses at the undergraduate level such as news gathering, news writing, news editor, news commentary, etc. are also offered in graduate level under the names of "news and writing topics", "news editing topics" and "news commentary topics". These courses, which have already been studied at the undergraduate level, appear again at the graduate level. Although the specific lectures by teachers may differ, it is inevitable that there will be repetition and it cannot reflect the proper teaching gradient.

The Defects of the Teachers' Structure Are Obvious. Due to the obvious defects in the structure of teachers, the graduates of professional degree still lay stress on the theory and ignore the practical business skills. The students who are trained cannot meet the needs of employers, and 
are not suitable for the rapid development of new media and financial media technology. Taking Shaanxi Province as an example, 27 colleges and universities have set up their major of journalism and communication, with 460 full-time teachers, including 58 professors / researchers which accounts for 12.6\%, 94 associate professors / associate fellows which accounts for 20.4\%, 308 lecturers and other teachers which accounts for $67 \%$. Although there are a large number of teachers, only $23.4 \%$ of teachers have real media experience. Most of the teachers pay attention to theoretical research, lack experience, and less contact with the industry, so the teaching content is out of line.

Table 2 The teachers' structure of the news and communication in Shaanxi province

\begin{tabular}{|c|c|c|}
\hline Job Title & Number of People & Proportion \\
\hline Professor / Researcher & 58 & $12.6 \%$ \\
\hline $\begin{array}{c}\text { Associate Professor / Associate } \\
\text { Researcher }\end{array}$ & 94 & $20.4 \%$ \\
\hline Lecturer / Other & 308 & $67 \%$ \\
\hline Total & 460 & $100 \%$ \\
\hline
\end{tabular}

Due to the lack of practical experience of full-time teachers, some colleges and universities improve their employment by hiring part-time teachers and holding lectures. However, due to funding constraints, it is difficult to meet the needs.

"Double Tutors System" Lacks Complementary Measures. MJC training implements the "double tutors system", that is, the tutor of the school and the outside tutor instruct the graduate students at the same time. [5] Although the original intention is good, the concrete implementation is not satisfactory. It is found that the "double tutors system" is difficult to implement. First, there are misunderstandings in the selection mechanism of the tutors outside the school. The selection of tutors outside the school tends to choose well-known and top managers in the industry. However, these people are busy working, have no energy to take on the role of tutors, have fewer meetings with students and become "naming" tutors. Second, there is a lack of complementary measures in the "double tutors system." The mechanisms such as the assessment mechanism and the corresponding remuneration are not perfect. The duties of the tutors outside the school are not clear enough. As a result, the tutors outside the school are not highly motivated and their sense of responsibility is not strong.

\section{The Countermeasures to Improve the Training Mode of MJC}

The graduate education of journalism and communication has just started. Timely summing up experience and analyzing and solving problems in training process are of great significance for improving the quality of talent training and promoting the development of master of journalism and communication.

Clearing Training Objectives, Highlighting the Characteristics of Professional Degree. In the MJC training objectives, we must further clarify the training objectives of the master of journalism and communication, and strengthen the distinction between different degree types. In the training of graduate students majoring in journalism and communication, we must insist on the combination of theory and practice, which is the basis for master's education in journalism and communication. One is to emphasize the application of the theory of journalism and communication in the practice of news in the teaching practice, and to cultivate the students' strong sense of news. The other is to strengthen the news practice skills. Good journalism skills are the "housekeeping skills" for graduate students majoring in journalism and communication. In the process of training, we should strengthen the training of the business skills of graduate students.

In addition, we should adapt to the social needs of media convergence and cultivate "all media" and "compound talents". With the development of internet dissemination, the trend of media convergence becomes more obvious. Media professionals not only need to acquire a wide range of specialized fields of knowledge, but also master new media technologies and business skills and 
cultivate high-quality "all-media reporters."[6] Training compound news dissemination talent, require practitioners with multi-disciplinary knowledge literacy, so as to master a higher ability to analyze and judge. For example, science communication requires mastery of knowledge and skills of journalism and communication and knowledge of science. International communication requires knowledge of international languages and politics and economics.

Improving the Course System of Professional Degree. There should be a clear distinction of curriculum system between professional master and academic master. The MJC curriculum system should be guided by practice so that students can master the news business skills, understand the development of the media and have extensive knowledge. [8] The academic master should focus on the study of theoretical knowledge and deeper exploration, focus on "refinement" and "deepness" Professional master should focus on the combination of theory and practice, focus on "broadness" and "wideness". [9]

The talents of journalism and communication lack the knowledge of relevant professional disciplines, so they cannot write reports with thickness, depth and strength when they conduct professional news reports. Some news media think that the training of high-level talents in journalism and communication should include the accumulation of knowledge of sociology, economics, law, literature and other subjects besides the professional courses. [10]

Improving the "Double Tutors System" Supporting Measures. We should speed up the improvement of the training mechanism of MJC tutors and establish a management method for the assessment of tutors outside the school. One is to strengthen the selection and assessment of tutors. In the selection of MJC tutors, we cannot apply the requirements of academic master tutors. We should pay equal attention to both theory and practice. Meanwhile, we should regard the requirements of tutor's practical skills and practical achievements as necessary conditions. The second is to establish the communication mechanism of tutors in school and outside the school. The tutor in school and the tutor outside the school should have regular communication mechanism, and they should cooperate with each other in the division of labor and make corresponding guidance for the specific situation of each student. To establish this communication mechanism, tutors in school should have the option of choosing the tutors outside the school. Schools can choose the tutors recommended by the tutors in school, and then schools rely on the tutor's selection rules to determine the tutors' configuration and then recruit graduate students. As a result, this can effectively strengthen the communication and cooperation between tutors in and out of the school, and improve the cultivation of graduate students.

\section{Conclusions}

The establishment of MJC professional degree is only 6 years. Compared with other professional degree types, it is still in the exploration period. It is necessary to further improve the system of talent training. The analysis of problems in MJC talent training is conducive to the healthy and orderly development of this degree, and also has reference value for other professional degree graduate students.

\section{References}

[1] D.L.Liu: A Probe into the Setting and Training Mode of Master of Journalism and Communication[J], Chinese Journalist, 2010(6):59-60.(In Chinese)

[2] T.C.Dong: The Training Goal and Model of the Master of Journalism and Communication[J], News and Writing, 2014(6): 65-68.(In Chinese)

[3] L.R.Li: Introduction to Journalism[M], Fudan University Press, 2006.(In Chinese)

[4] H.B.Tang: How does Professional Master Get out of the Training Mode of Academic Master[N], China Youth News, 2012-07-30(5).(In Chinese)

[5] H.Chen: Innovation of Training Model of Global News and Communication Talents[J], Modern Communication, 2015(5):140-143.(In Chinese)

[6] W.B.Kuang: Introduction to New Media[M], China Renmin University Press, 2015.(In Chinese) 
[7] J.Sun: Research on the Training Mode of Master of Journalism and Communication in the New Era[J], News Front, 2015(19):105-107.(In Chinese)

[8] W.X.Zhao: Research on the Characteristics of the Training of Fusion Media Talents in Domestic Universities[J], Journal News Research, 2017(2):35-36.(In Chinese)

[9] Z.Y.Yin: Some Understanding of the Training Mode of Creative Media Talents, News Tribune, 2017(5): 118-119.(In Chinese)

[10] C.Y.Xia: What Kind of Journalists do We Need[J], Media, 2015(6): 58-61.(In Chinese) 